\title{
TITLE INDEX OF VOLUME 10
}

\section{EDITORIALS}

\section{UNITED NATIONS ACTIVITIES}

General Assembly

- World Charter for Nature

- Export of Hazardous Products

UNEP

- System-wide Medium-term Environment Programme

- The Protection of the Ozone Layer (Harald Heimsoeth)

- Barcelona Convention

- 11th Session of the Governing Council

UNCTAD

- Agreement on Tropical Timber

- Tropical Timber Seminar

- Conference on Tropical Timber

ECE

- Progress in Most Areas

- The Thirty-eighth Session

IMO

- London Dumping Convention. 7th Consultative Meeting

LOS

- La Nouvelle Convention sur le Droit de la Mer. Structure et Problèmes Généraux (Tullio Treves)

- Sea Convention Signed

- Pollution from Seabed Mining: Legal Safeguards (E.D. Brown)

Water Pollution Control

\section{OTHER INTERNATIONAL DEVELOPMENTS}

Transfrontier Pollution

Red Sea Treaty

South Pacific Forum

World National Parks Congress

- Extracts from Statements

Ramsar Convention: Protocol Adopted

International Harmonization of Terms in Environmental Chemicals Control Law (Martin Uppenbrink and Jürgen Knebel)

Economic Implications of Various Compensation Limits for Oil Pollution Claims (Henri Smets)

Parliamentary Initiatives

A New Ocean Treasure?

Migratory Species. Towards an Agreement on the Western Palearctic Elizabeth Haub Prize

The World Charter for Nature

IUCN

- Environmental Law Information System (ELIS)

CEDE

- Sea Convention Discussed

\section{REGIONAL ACTIVITIES}

EP

- New Initiatives

- Global 2000

- Application of Community Law

- Law of the Sea

EC

- Transfrontier Shipment of Hazardous Wastes

- New Approach?

\section{$1,33,77,109$ NATIONAL AFFAIRS}

\section{Belgium}

- Environnement et Droits de l'Homme (L.-P. Suetens)

Canada

- Forest Renewal: Federal Guidelines 12

37

- Seal Products

88 China

- New Law 60

2 - Order to Preserve Wildlife 140

34 Germany, F.R.

88 - Chemicals Control

110 - Environmental Forum

- Clean Air Regulations

58

41 Ghana

88 - The New Investment Code 15

121 India

- New Forest Policy

85 Malaysia

120 - Klias Peninsula National Park de-Gazetted (Neil Stevens)

Netherlands

83 - Air Pollution Control. National Targets and Regional Implementation (Hubert Meiners)

UK

22 USA

87 - A Step Forward? An Economic Approach in Air Quality Management (Gordon L. Brady)

- LOS Policy

\section{SELECTED DOCUMENTS}

2 UN/GA

- World Charter for Nature

- Consideration and Adoption of the Revised Draft World Charter for Nature

- Export of Hazardous Products

UNEP

47 - System-wide Medium-term Environment Programme 24

- Achievements in Environmental Law

- Annex I: Research and Monitoring

- Annex II: Guidelines for Information Exchange

- Barcelona Convention. 3rd Ordinary Meeting

UNCTAD

- Meeting on Tropical Timber

EP: Motions

- On the Consolidation of Precautionary Measures Concerning

Chlorofluoro-carbons in the Environment

- On European Nuclear Safety Policy

92

EEC

- Proposal (Extracts) On Action by the Community Relating to the Environment (ACE)

- Motion for a Resolution On the Responsibility of the Member States for the Application of Community Law

- Draft Motion for a Resolution On the Signature and Ratification of the Convention of the Law of the Sea

- Proposal for a Directive On the Supervision and Control of Transfrontier Shipment of Hazardous Wastes Within the European Community

13th South Pacific Forum

93 - On Nuclear Testing and Waste Disposal

94 - On Fisheries and Law of the Sea Convention 
- Resolution on US Policy on Highly Migratory Species

International Law Association

- Rules of International Law Applicable to Transfrontier Pollution

Canada

- Seal Products

China

- Environmental Protection Law

Germany, F.R.

- Speech of Mostafa K. Tolba to the 'Umweltforum' (Extracts)
26 India

- Draft: National Forest Policy (Extracts)

27 - Prime Minister's Inaugural Address at the Conference of State Forest Ministers

Red Sea Convention (Regional Conference of Plenipotentiares on the Conservation of the Marine Environment and

Coastal Areas in the Red Sea and Gulf of Aden

74 IUCN

- Declaration of the World National Parks Congress 62

73 - Recommendations of the World National Parks Congress 63

Convention on Wetlands of International Importance Especially as Waterfowl Habitat

\section{AUTHOR INDEX OF VOLUME 10}

Brady, Gordon L., 3

Brown, E.D., 122

Heimsoeth, Harald, 34

Knebel, Jürgen, 47

Meiners, Hubert, 17
Smets, Henri, 52

Stevens, Neil, 13

Suetens, L.-P., 137

Treves, Tullio, 78

Uppenbrink, Martin, 47 